\title{
The potential accessibility to workplaces and working-age population by means of public and private car transport in Szczecin
}

\begin{abstract}
Commuting to work is one of the key motivations for people to move around cities or other regions. For the purpose of this study, the city of Szczecin in Poland has been selected, where the modal division of transport includes public transport (bus, tram) and private transport (car). The maps present the spatial distribution of citizens within a working area as well as precise locations of workplaces registered in the REGON database. The main objective of this study is to analyse the potential accessibility of workplaces and the working-age population of the city using the abovementioned modes of transport, and to indicate the places less accessible by public transport and car for commuting purposes. The study presented herein is based on data from 2018. The calculated average accessibility by different means of public and private transport as well as the potential accessibility quotient are presented in the form of box plots.
\end{abstract}

Keywords

Public transport $\bullet$ car transport $\bullet$ GTFS $\cdot$ workplaces $\bullet$ working-age population

-Szczecin

\section{Introduction}

Potential accessibility is a key concept and method of calculation in transportation research. Countries, regions and cities are analysed using this indicator. The potential accessibility theory was based on the location of travel sources and the destinations that can be reached using different modes of transport (Geurs \& van Wee 2004; Hansen 1959; Harris 1954; Vickerman 1974). The easiest way to explain this method is that demand for transport services is created naturally in highly populated places, as people themselves generate it on a daily basis. People travel in order to satisfy their daily needs and they use different means of transport to do so. However, work (Merchant \& Nemhauser 1978) and shopping (Farber et al. 2014; Widener et al. 2015) are still two main motivations behind everyday commuting. In the case of shopping, it is not an obligatory daily activity, and some people only shop at weekends when traffic congestion is less severe and the means of public transport are not so crowded. Commuting to work is obligatory, though. It significantly affects people's daily lives. Most people commute to work every weekday (O'Kelly \& Niedzielski 2009; O'Kelly et al. 2012). Everyday commuting is a popular issue being studied by numerous researchers (Boussauw et al. 2011). As a result, more and more data is available, which can be used to improve the operation of both public and private transport systems during the morning rush hour (Goliszek 2017; Rosik et al. 2021). Observations of everyday commuting patterns allow us to indicate factors that directly reduce the accessibility of certain places, as well as allowing us to make some recommendations for the future (Niedzielski 2006; Niedzielski \& Boschmann 2014; Niedzielski \& Śleszyński 2008; O'Kelly \& Lee 2005; O'Kelly \& Niedzielski 2009; O'Kelly \& Niedzielski 2008; Owen \& Levinson 2015; Rosik et al. 2010; Shearmur 2006; Shirgaokar 2014; Wang \& Chen 2015; Yongling \& Guonan 2009).

The pioneer in the search for the optimal path was Torsten Hägerstrand (1970). He used a physical approach involving the
Sławomir Goliszek $\mathbb{C}^{1,2}$

'Department of Spatial Organization, Institute of Geography and Spatial Organization, Polish Academy of Sciences, Warsaw, Poland

${ }^{2}$ The Digital Geography Lab, Department of Geosciences and Geography, University of Helsinki, Helsinki, Finland e-mail: sgoliszek@twarda.pan.pl

Received: 25 September 2020

Accepted: 13 July 2021 study of how events occur in a space-time framework (time geography) in order to determine relations between different constraints and daily human activities. Time geography is based on the concept that in space-time the individual describes a path within a particular context. The path is captured within a net of constraints. Time geography uses the concept of the space-time path to describe the individual's trajectory, and the space-time prism, which depicts the space-time range that the individual is capable of covering given the constraints. This concept provides effective methods to analyse daily human activities in the spacetime context (Hägerstrand 1970; Miller 1991; Hongbo \& Shih-Lung 2007).

Both potential accessibility at the local level and the search for optimal travel paths are well in line with the objectives of this text, the main objective of which is to indicate places where intense traffic flows generated by means of public and private transport are observed, then to compare them with areas with a high workingage population potential (travel source potential) and workplace potential (travel destination potential). This approach indicates the places of potential increased traffic streams in local travel. The potential quotient is an approach that fills a research gap that focuses on finding optimal travel paths between two gravity fields. The results of this study may be used by researchers and urban planners who would like to apply accessibility analysis to different projects, and enable them to compare the two means of transport and search for an optimum solution.

Following the introduction, there is a literature review of studies on potential accessibility methods used in commuting. This section is followed by a brief description of the case study analysed and the data used in the paper. Then the public and private transport modes are described and, in the next step, the methods used in the accessibility study. The last section is a description of the results of the accessibility potential of the 
working-age population and jobs available. Finally, a discussion on the variation of accessibility, as discussed in other works, is presented and conclusions are drawn from the accessibility results of the potential quotients in relation to the other research mentioned.

\section{Literature review}

The very first studies mainly focused on commuting to work by private car (Kent 2014). Using private transport models became widespread and it was possible for almost everyone to build such a model on the basis of observable phenomena. Nowadays, such analyses are usually based on data provided by Google Maps API, TomTom (Moya-Gómez \& García-Palomares 2017) or INRIX (Sweet et al. 2015), which are used to create models or matrices allowing transport accessibility to be calculated (Wang \& Xu 2011). Recently, more and more researchers have started to analyse multi-modal solutions in everyday commuting (Rosik et al. 2018). A lot of data on people's movements and the locations of workplaces is available free of charge (Bok \& Kwon 2016). Thus, it is possible to create a model of accessibility by public transport for almost every region of the world. Currently, the most common data format used for modelling accessibility by public transport is the GTFS format (General Transit Feed Specification, Hadas 2013). Data in this format is usually published and made available by institutions managing urban or regional transportation systems (Delling et al. 2014; Farber et al. 2014; Goliszek \& Połom 2016; Karner 2018; Wessel \& Widener 2016; Wessel et al. 2017; Widener et al. 2015; Widener et al. 2017). The GTFS data format allows us to precisely analyse travel times provided in timetables. Using this format makes it possible for researchers to determine time gaps in the analysed timetables (Allen \& Farber 2019). So far, the researchers who actually used this type of data mainly focused on commuting to shops (Widener et al. 2017), shopping centres (Farber et al. 2014), health care facilities (Neutens 2015) and cultural and educational facilities (Allen 2019; MartínezJiménez \& Salinas-Pérez 2019). At the same time they emphasised large disparities in accessibility to public transportation (El-Geneidy et al. 2015; El-Geneidy et al. 2016). The above-mentioned authors also revealed some drawbacks of using the GTFS data format for time analyses, resulting mainly from the frequency of public transport (Fransen et al. 2015; Lei \& Von u Thakuriah 2012). This limitation may also affect the final results of the analyses (Farber et al. 2016; Stępniak et al. 2019; Wessel \& Widener 2016; Wessel et al. 2017). The researchers also pointed out some disparities in accessibility resulting from the Modifiable Temporal Unit Problem (MTUP). These inequalities concern both public and private transportation systems (Levinson \& King 2020). As for the public transportation systems, the results are usually aggregated and then averaged in order to assess travel times. In this study the authors decided to analyse data on travel times at 8 a.m. However, analyses using GTFS data may be interpreted in many ways (Ting \& Church 2010) and presented on highly detailed maps (Stępniak \& Goliszek 2017; Moya-Gómez \& GarcíaPalomares 2017). Szczecin is a city that has already been analysed in the context of accessibility by means of public transport (Goliszek 2017; Goliszek \& Połom 2016; Poelman \& Dijkstra 2015; Stępniak \& Goliszek 2017; Steppniak et al. 2019). One of the previous articles by the author of this study was on accessibility to workplaces by public transport during the morning rush hour. The author used similar data, from the REGON register, yet only companies with more than 10 employees were taken into consideration, thus excluding companies with less than 10 employees (Goliszek 2017). After publishing the above-mentioned study, a growing interest in accessibility to workplaces in Szczecin has been observed. Thus, the study presented herein is more detailed, as this time the author was granted full access to the REGON database, which made it possible to assess traffic flows during the morning rush hour quite precisely.

\section{Study area}

Szczecin city is located in north-western Poland. The city has a current population of 376,000 people (according to the data of City Hall in Szczecin, n.d.; bottom right corner of Figure 1). The issue of accessibility to different services and facilities in Szczecin by public transport has already been raised in several other studies (Goliszek 2017; Goliszek \& Połom 2016; Poelman \& Dijkstra 2015; Stępniak \& Goliszek 2017; Stępniak et al. 2019). In areas of Szczecin, the socio-economic layout and the distribution of travel sources and destinations are very different. The left-hand side of the city is home to more people and more workplaces. As a result, residents on the right-hand side of the city often travel to the other side of the river during the day, which generates increased traffic here.

\section{Data analysed}

In order to investigate the potential accessibility to workplaces by means of public and private transport, the data concerning all companies having their registered office in Szczecin was acquired from the National Business Registry (REGON). The REGON database provides complete information on the location of a given company and the declared number of employees, given in the following ranges: 1-9, 10-49, 50-249, 250-999, and more than 1,000 people. In the case of companies employing more than 1,000 people, the REGON data was verified; detailed data on the number of employees was acquired via email or during phone interviews. The number of workplaces for the other ranges - in companies employing less than 1,000 people - was calculated using half the number of employees in each range. Adopting such an approach may not be an ideal solution; yet it is the only possible method in this case.

All the analysed companies were assigned geographic reference data $(X Y)$ in order to indicate their exact location. According to the National Business Registry (Central Statistical Office, REGON), there were approximately 68,000 companies registered in Szczecin in 2018. The map in the bottom left corner of Figure 1 shows their spatial distribution. When it comes to potential accessibility to the citizens of working age (18-60 for women, 18-65 for men), the data published by the City Hall of Szczecin was used. In 2018, the working-age population comprised 217,600 citizens (City Hall of Szczecin). The detailed data for different age ranges was originally assigned to 37 housing estates. The city of Szczecin is divided into 1,869 census areas and the population figures for these areas is from 2011. In the article, the population in an estate was estimated using the census enumeration area population data from 2011. The number of residents was updated using data from 2018. Therefore, the analysis presented in this article may be considered very detailed. For each census area a centroid has been designated, acting as a link between the areas. The census centroid is a spot with the highest population density. Locations of the centroids have been confirmed using satellite images in which the location of housing estates is clearly visible (Goliszek 2021). However, the author calculated the number of people of working age living in smaller spatial units, which are census areas. Additionally, the data on the spatial distribution of citizens living in districts where intense housing development processes are taking place was verified using up-to-date ortophotomaps. The map in the bottom right corner of Figure 1 shows the spatial distribution of the working-age population. There are 1,869 census areas in Szczecin in total; therefore, the analysis of the potential accessibility presented herein is characterised by a high degree of accuracy. The final map of accessibility (Fig. 2) shows the aggregated results for the following districts: Zachód, Prawobrzeże, Północ, Śródmieście. 
Public and private transport model

The first data in GTFS format in Poland appeared in Szczecin in 2008. Before that, accessibility researchers always took the limited range of impact of bus/tram stops into consideration. However, spatial accessibility is one of the planning methods used in public transport (e.g. Gadziński \& Bul 2017). However, the GTFS data format allows us to analyse public transport spatial accessibility more accurately than the methods previously used (Gadziński \& Beim 2010). In order to calculate potential accessibility, a public transport model based on GTFS data was created. The basic road network, including pedestrian paths and connecting particular travel sources and destinations, was created on the basis of selected sections of roads/streets taken from the BDOT 10k database of topographic objects (Goliszek 2021). This network is visible in the top left corner of Figure 1. The author assumed that the average walking time between the points was $4.5 \mathrm{~km} / \mathrm{h}$, as in the study by Stępniak \& Goliszek (2017). In the literature, there is no consent on the average walking speed to be adopted when analysing transport accessibility; for example, Reyes et al. (2014) claim that the average walking speed for children is $3.2 \mathrm{~km} / \mathrm{h}$, while Fransen et al. (2015) and Ritsema et al. (2005) state that it is $4 \mathrm{~km} / \mathrm{h}$; at the same time, Fransen et al. claim that it is also the average walking speed for adults, and Ritsema et al. (2005)emphasise that this speed is concerned with linear motion. The public transport network was based on GTFS data from October 2018. The GTFS data is published by the City Transport Authority of Szczecin (GTFS open data Szczecin 2018: https://www.zditm.szczecin.pl, upper left corner of Fig. 1). It should be mentioned that the regional railway is integrated in the fare system in Szczecin but there are only a few operating passenger railway stations in the city. Thus, the trains do not play an important role in everyday commuting within the city limits.

Nowadays, private transport models are often based on data published by different GPS systems and websites. These types of websites or applications gather real-time data on private car travel times for selected sections of a particular road network (Lagrell et al. 2018; Wang \& Xu 2011; Wang et al. 2013). As for the private transport model, there are also four components - reaching a car, driving time (calculated using Google Maps ${ }^{\circledR}$ API data), parking and walking to the final destination. The value that is added as the parking time is the walking time between the centre of a particular census area and the nearest road/street. In fact, it is virtually impossible to measure parking time due to its variability in different cities in Poland. Actually, the values may be random. The only places where the parking time may be assessed are some newly built buildings with monitored parking areas. However, a correlation was demonstrated between peak hours and the possibility of parking in city centres (Assemi et al. 2020; Goliszek 2021). There are several companies providing such services (e.g. TomTom or Google Maps/Transit). However, Google Maps API is the only application that has access to such data. TomTom gathers, processes and sells data to its users. The easiest way to download the data from Google Maps API in real time is to use a dedicated application written in one of the programming languages - for example, Python 2.7. The author of this study developed an original road model for private transport in Szczecin on the basis of data downloaded from Google Maps API (Wang \& Xu 2011), using a dedicated application written in Python 2.7. The downloaded sets of data for October and November 2018 make it possible to compare both models. The possibility of comparing public and private transport systems has created lots of new research opportunities and provided numerous interesting results. Such analyses, taking different times of the day into consideration, give an answer to the question of when the differences in the functioning of private and public transport are the smallest throughout the day (Beria et al. 2017; El-Geneidy \& Levinson 2007; Salonen \& Toivonen 2013; Shirgaokar 2014).
The Google Maps API approach is not free of concerns. First of all, an ordinary user without a paid licence to Google Maps API Premier is subject to a daily query limit of 2,500 geolocation requests and is likely to experience some 'hiccups' in executing the tool. We welcome feedback from users with a Google Maps API Premier licence. Second, all data used in the computation are maintained by Google, and thus a user has neither control over its quality nor any editing rights. While Google's road network has a reputation for good quality, no data is completely free of errors. Furthermore, the tool can only generate the contemporary travel time by accessing the most updated road network data in Google. Google collects driving time data from users, converts it into road sections and makes it available on Google Maps (Wang \& Xu 2011; Fielbaum \& Jara-Diaz 2021).

\section{Methods and time research}

The potential accessibility indicator is a gravity-based indicator. Harris (1954) and Hansen (1959) are regarded as the forerunners of this method and R. Vickerman was the first to use it to express the effects of transport investments (Vickerman et al. 1999).

Accessibility index $(\mathrm{Ai})$ is defined as the level of accessibility of a given place/area. The private car travel time between a pair of census areas in Szczecin ( $i$ and $j$ ) is shown as $t i j$ and it is reduced by a distance decay function $f(t i j)$. The measure of attractiveness of the travel destination is the working-age population WPOP and workplaces WP The general formula for the potential accessibility of the working-age population is as follows:

$$
A \mathrm{i}(W P O P) i=\sum j W P O P j \mathrm{f}(t i j)
$$

while the formula for the potential accessibility of the workplaces is:

$$
A \mathrm{i}(W P) i=\sum j W P j \mathrm{f}(t i j)
$$

The term 'workplaces potential (WP)' was also used by O'Kelly \& Lee (2005), O'Kelly \& Niedzielski (2008), Niedzielski \& Boschmann (2014) and Goliszek et al. (2020). The potential accessibility of the working-age population is generally the population potential divided by the share of people in a given age group. The ratio of the working-age population potential and the workplaces population of a census area is identified as the potential quotient (Qi) (Beria et al. 2017, Goliszek et al. 2020), calculated according to the following formula:

$$
Q_{i}=\frac{\mathrm{A}(W P O P) i}{\mathrm{~A}(W P) i}
$$

Coffey (1978) used the potential quotient indicator for regional studies. However, it is worth emphasising that the results of potential quotient analysis are highly affected by the distance decay function applied (Rosik et al. 2020). One of the most frequently used distance decay functions is the exponential one (Beria et al. 2017): $f(t i j)=\exp (\beta t i j)$, where the $\beta$ parameter differentiates the degree at which the attractiveness of the destination decreases. In smaller cities the distance decay function (time during which the attractiveness of the destination decreases) is calculated for shorter distances. In the case of commuting to work in Szczecin, its value is 0.023105 , which means that the attractiveness of a particular destination decreases by half during a 30-minute journey. This value of the $\beta$ parameter results from the average time citizens spend on everyday commuting to work by different means of public and private transport, which was estimated on the basis of the data published in Comprehensive Traffic Research in Szczecin 2016. The same distance decay function was used 

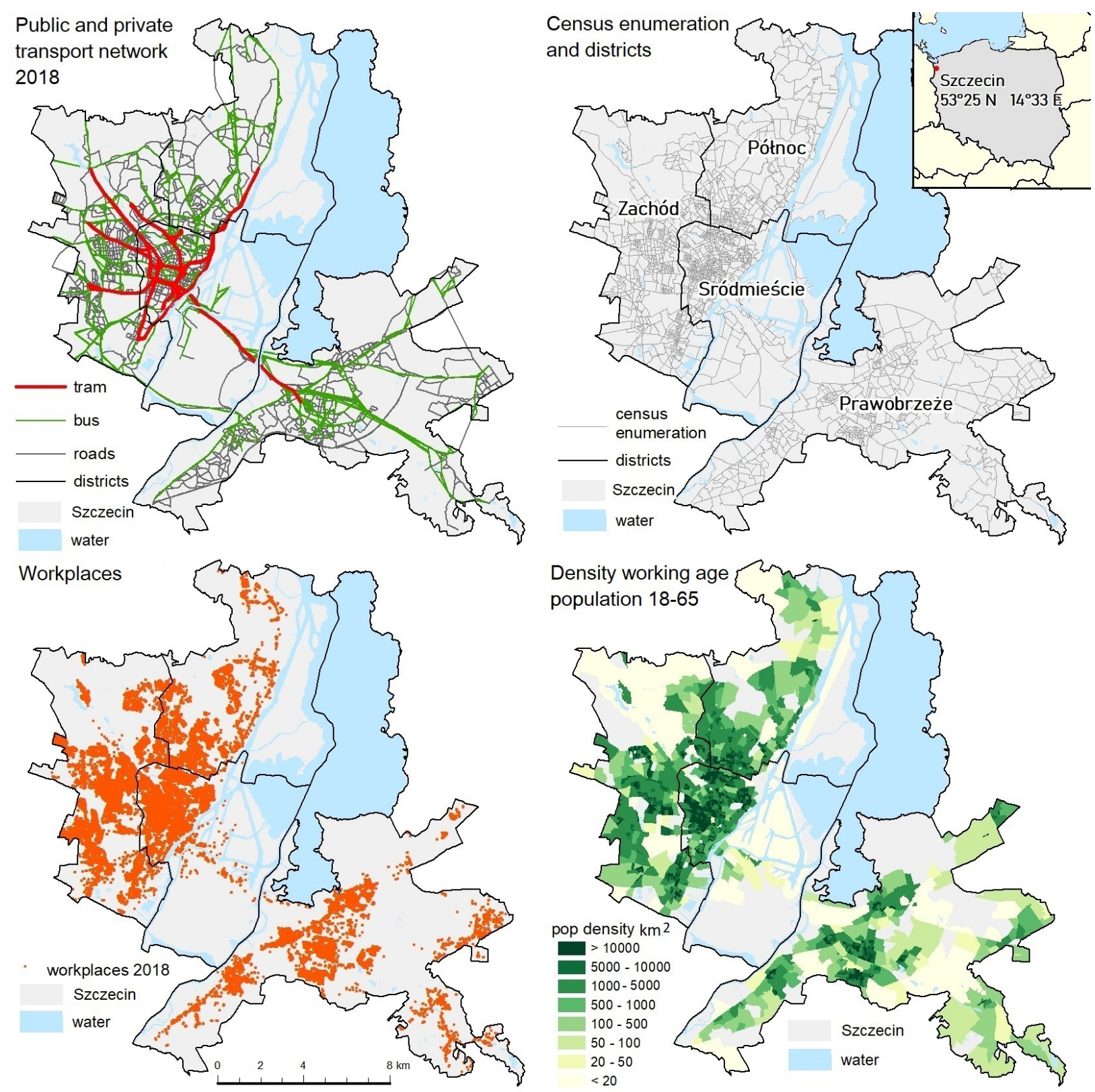

Figure 1. Spatial distribution by: PuT (public transport routes) and PrT (private car routes), census enumeration and districts, workplaces 2018 and working-age population (18-60 for women and 18-65 for men) Source: elaboration - own study based on GTFS and City Hall data

for both public and private transport for comparative purposes. Increasing the sharpness of the function (e.g. to a 20-min journey) would affect the result for public transport - and have a greater influence on the concentrations of workplaces and people of working age. The potential accessibility and potential quotient values for both public and private transport were calculated with the assumption that the departure time is 8 a.m.

\section{Results}

The potential of workplaces and people of working age

The maps of the potential accessibility of the workplaces and the working-age population show spatial distribution of accessibility in Szczecin, with higher values clearly visible in the city centre. This is a typical spatial distribution of the potential accessibility that changes according to the distribution of workplaces or population (Goliszek et al. 2020). The potential accessibility maps show peripheries and the core of the analysed area that is always characterised by the highest accessibility. Some differences may be observed when comparing separate maps for public and private transport. The value of the potential accessibility indicator is affected not only by the population, but also the travel time between travel sources and destinations. Shorter car travel times (cars are usually faster than buses or trams) make the potential accessibility of private transport higher and more balanced. In the case of public transport, applying the 30-minute distance decay function, the mass of a particular destination decreases faster. Thus, the sum of all masses is also lower. In order to calculate travel times by public transport the door-to-door approach was applied 
Potential accessibility of the workplace (public transport)

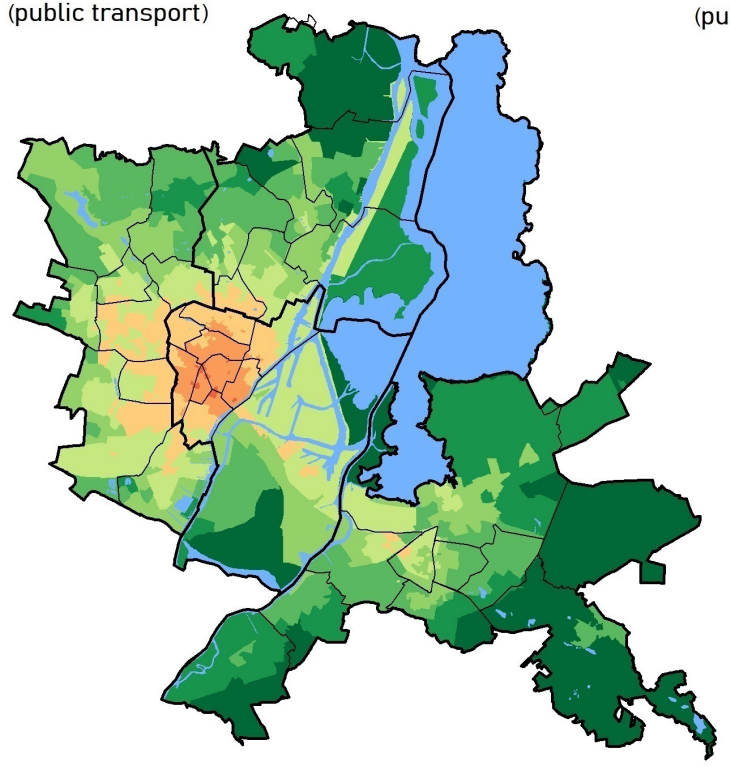

Potential accessibility of the workplace (private transport)

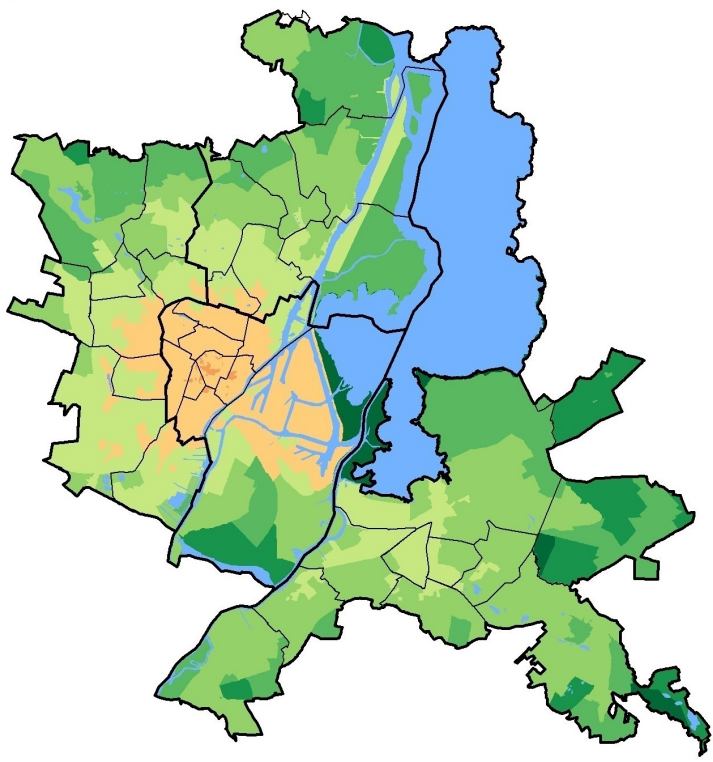

Potential accessibility [\%] $100=$ average

$\begin{array}{lllllllll}>150 & 137.5 & 125 & 112.5 & 100 & 87.5 & 75 & 62.5 & 50<\end{array}$
Potential accessibility of the working-age population (public transport)

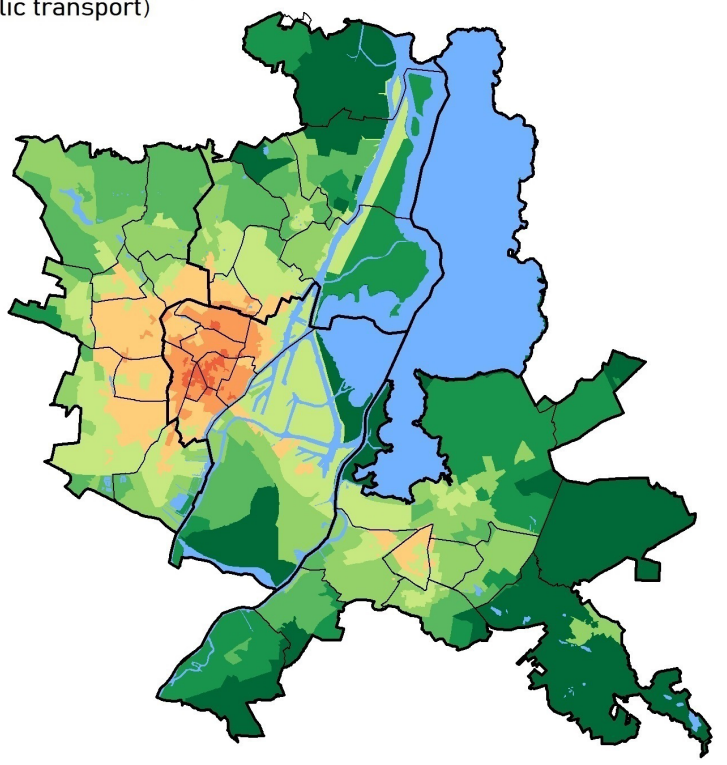

Potential accessibility of the working-age population (private transport)

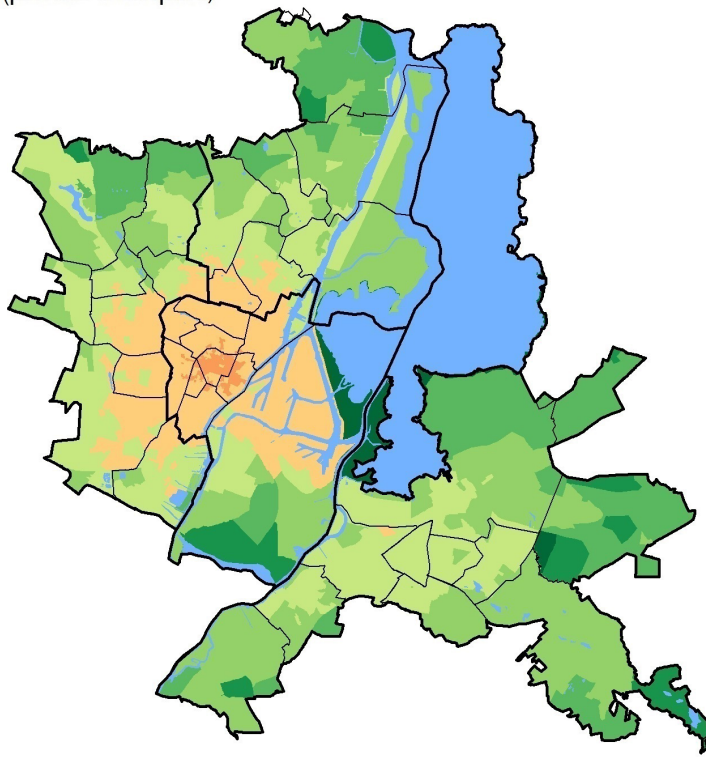

water
$8 \mathrm{~km}$

Figure 2. Potential accessibility of working-age population and jobs by public and private transport Source: own elaboration

(Salonen \& Toivonen 2013), including time needed to reach a tram/ bus stop, waiting time, changing time (if needed) and returning time, calculated according to the walking model. In the case of private transport, the following elements were taken into account: time needed to reach the car, car travel time (according to the private transport model created on the basis of Google Maps API data), and parking time. The sum of car travel times will always be lower than the sum for public transport. Only during morning and afternoon rush hours can the means of public transport compete with private cars. However, this competitiveness means that, on certain sections, buses and trams can reach the same speed as private cars. The results for both private and public transport may be similar if there is a high frequency of public transport services and when the public transport does not use the road system and, therefore, their operation is not affected by traffic congestion (Fig. 2 and 3). 


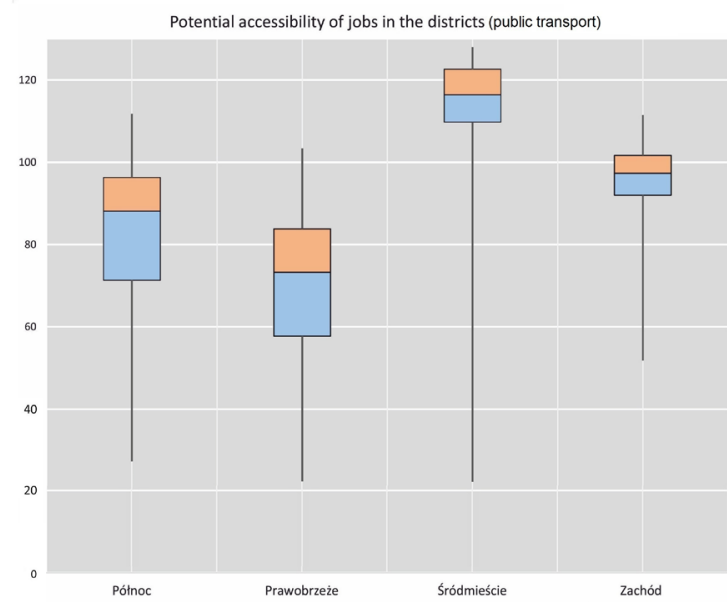

Potential accessibility of jobs in the districts (private transport)

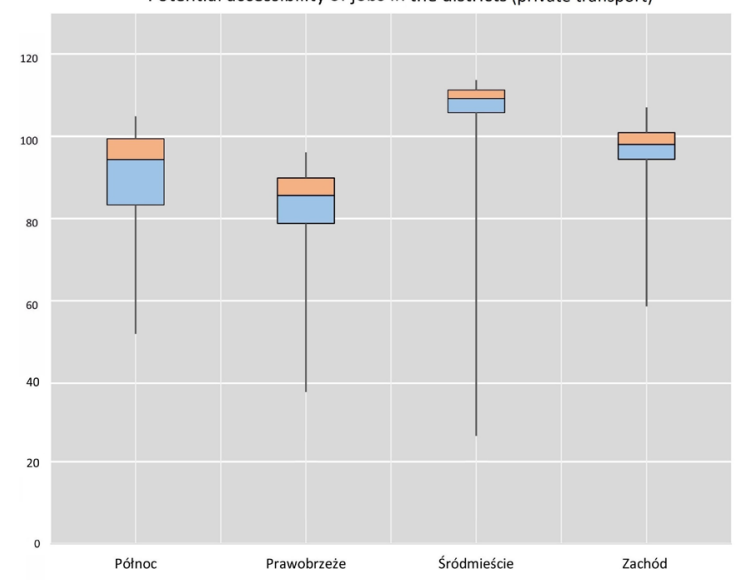

Potential accessibility of the working-age population in the districts (public transport)

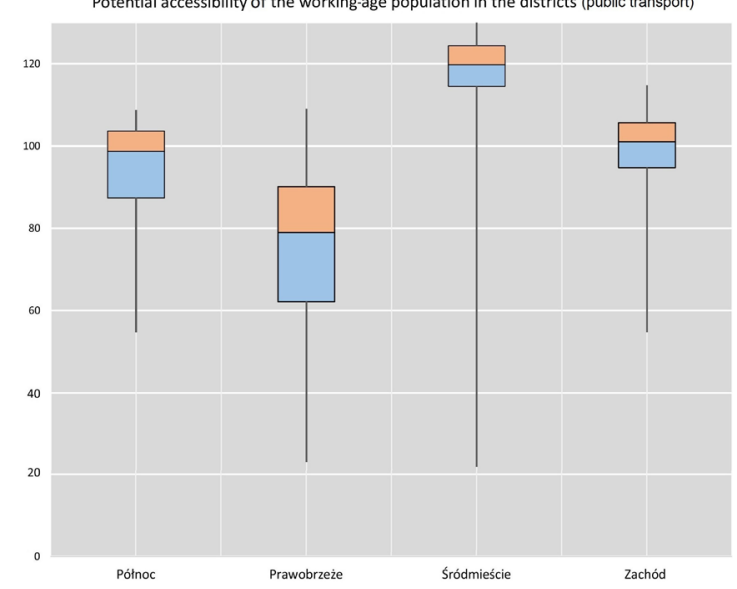

Potential accessibility of the working-age population in the districts (private transport)

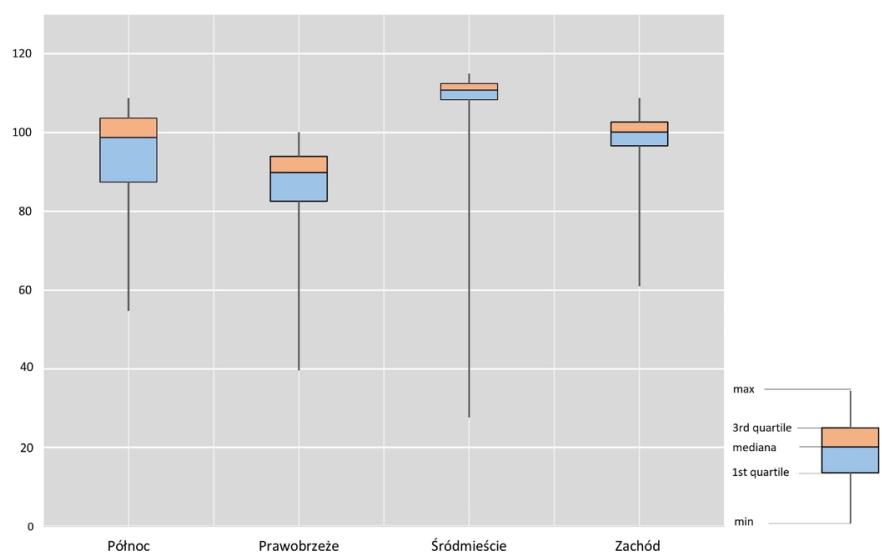

Figure 3. The results of the division accessibility and the working-age population by public and private transport, divided into districts Source: own elaboration

Quotient of the potential of workplaces and people of working age

The final maps of potential accessibility in Szczecin show areas where the workplaces potential is higher than the potential of the working-age population. The first map presents values of the potential quotient indicator for public transport, the second for private transport. On the public transport map, there are three clearly visible areas where the population potential is higher, and two where the workplaces potential prevails. A surplus of the workplaces potential is observed in the central part of the city - Sródmieście - and in the area located southwest of the city centre. A surplus of the working-age population potential is observed in the northern, south-eastern and northeastern parts of the city. The surplus of the workplaces potential indicates areas where there is a demand for labour, while the surplus of the working-age population potential indicates areas where labour supply is present. In the case of public transport, which is characterised by larger disparities in travel time, the surpluses are generally higher. The surplus of the working-age population potential observed in the northern and eastern parts of the city (Prawobrzeże) results in larger passenger flows in both directions and, consequently, higher traffic congestion. According to the estimation by Goliszek (2017), approximately 22,000 people commute every day from Prawobrzeże to the city centre. These high passenger flows between Prawobrzeże and Śródmieście were the main premise for the development of the fast tram network in Szczecin. Such an intense movement of people between Prawobrzeże and Śródmieście is also mentioned in the Comprehensive Traffic Research in Szczecin 2016 report. Large passenger flows are also observed between Północ and Śródmieście as well as in the southern part of Zachód (Fig. 4).

The analysis of the surplus of the workplaces potential for public transport showed that the highest values are observed in Śródmieście and Zachód. On the other hand, Prawobrzeże and Północ are two districts where the surplus of the workingage population potential is observed. Large numbers of people commute every day from Prawobrzeże and Północ to Śródmieście and Zachód using means of public transport. When it comes to private transport, the areas where the surplus of the workplaces potential was identified are the same as in the case of public transport - Śródmieście and Zachód. However, there are some differences concerning the surplus of the working-age population potential. The values are more similar to the average in Północ, while the largest disparities are observed in Prawobrzeże. Yet, the values are more balanced for private transport. The number of citizens commuting from Zachód and Prawobrzeże is considerably large. However, in the northern part of the city there are several different routes that can be chosen. In Prawobrzeże there is no alternative route to Śródmieście, and the two bridges, visible in Figures 5 and 6 , are the most problematic sections; the highest traffic congestion is observed there. 


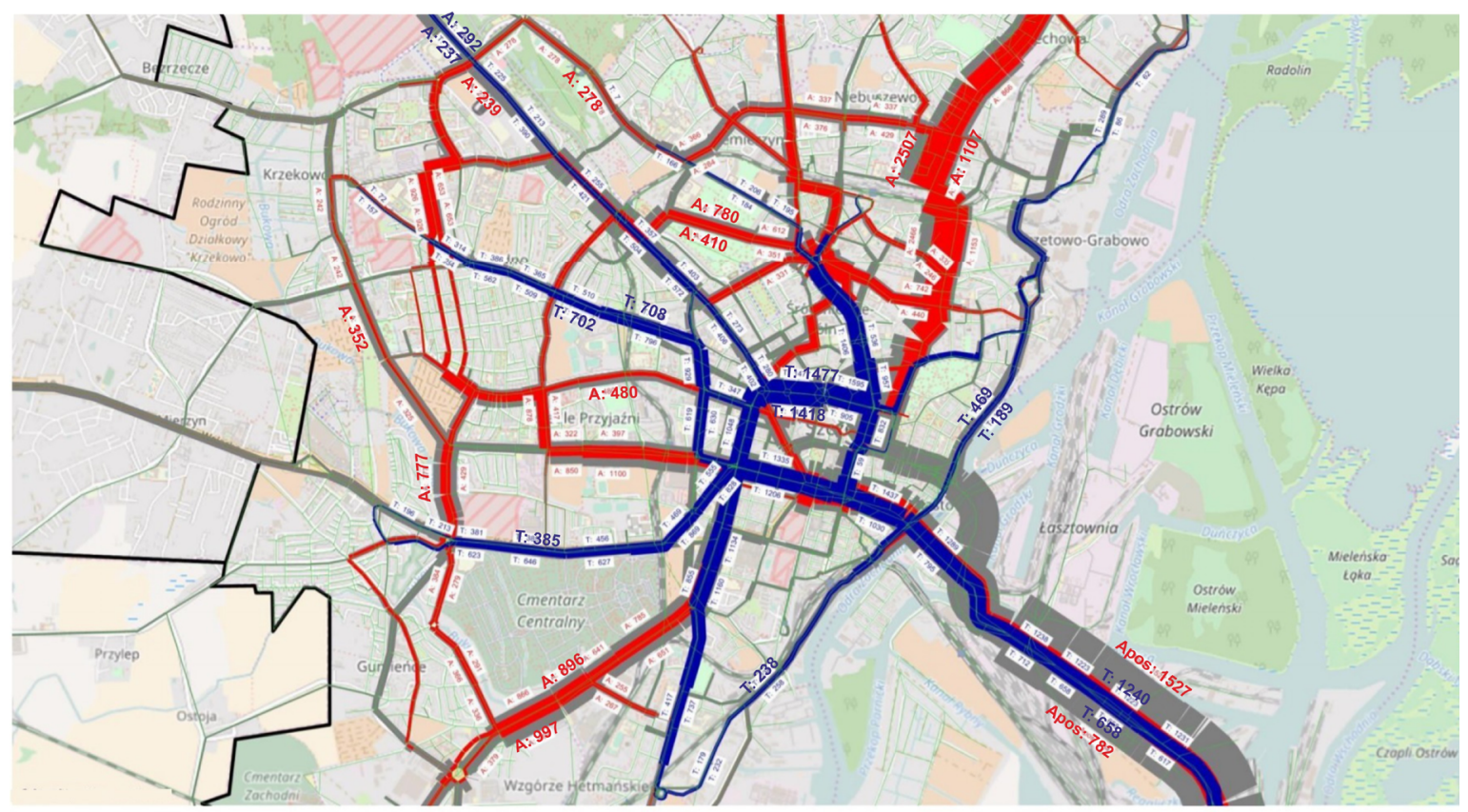

Traffic flows at the South Summit

Individual transport (car) no data available Public transport (bus)

Public transport (tram)

Figure 4. Load of public and individual communication networks at the South Summit in the afternoon - model 2016 Source: Comprehensive Traffic Research in Szczecin 2016

Quotient of potential accessibility of potential working-age population and jobs by public transport

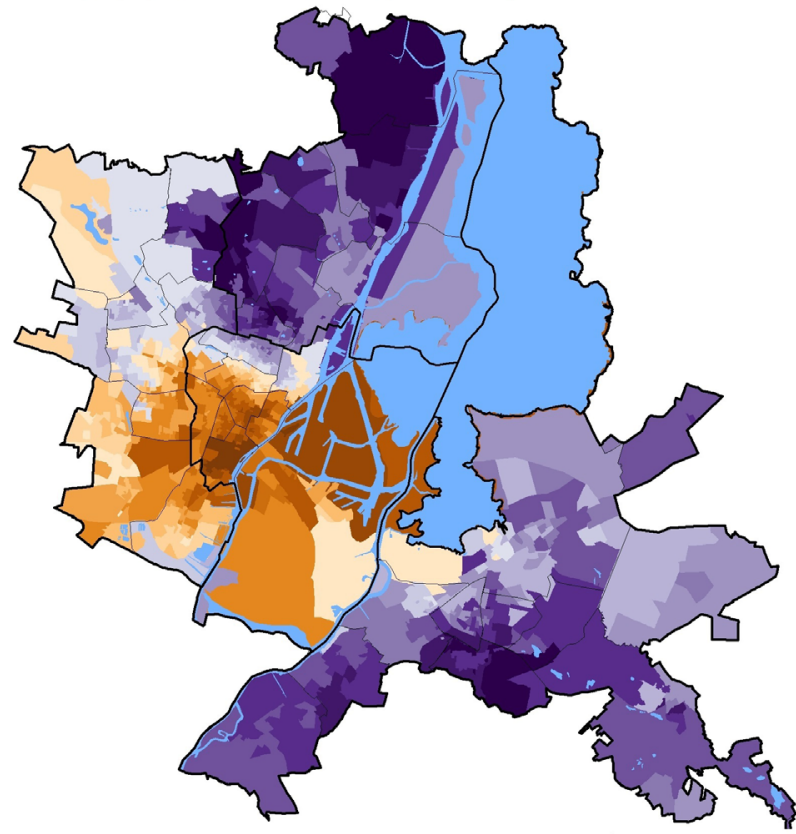

Quotient of potential accessibility

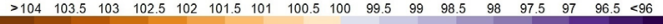

Quotient of potential accessibility of potential working-age population and jobs by private transport

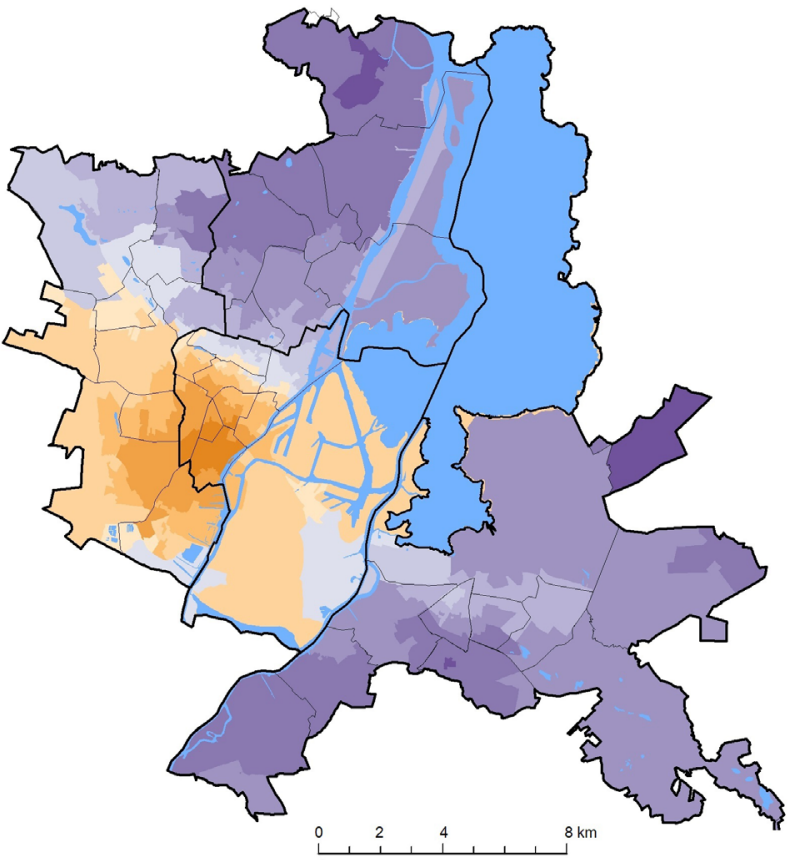

Figure 5. The quotient of the working-age population potential and jobs by public and private transport Source: own elaboration 

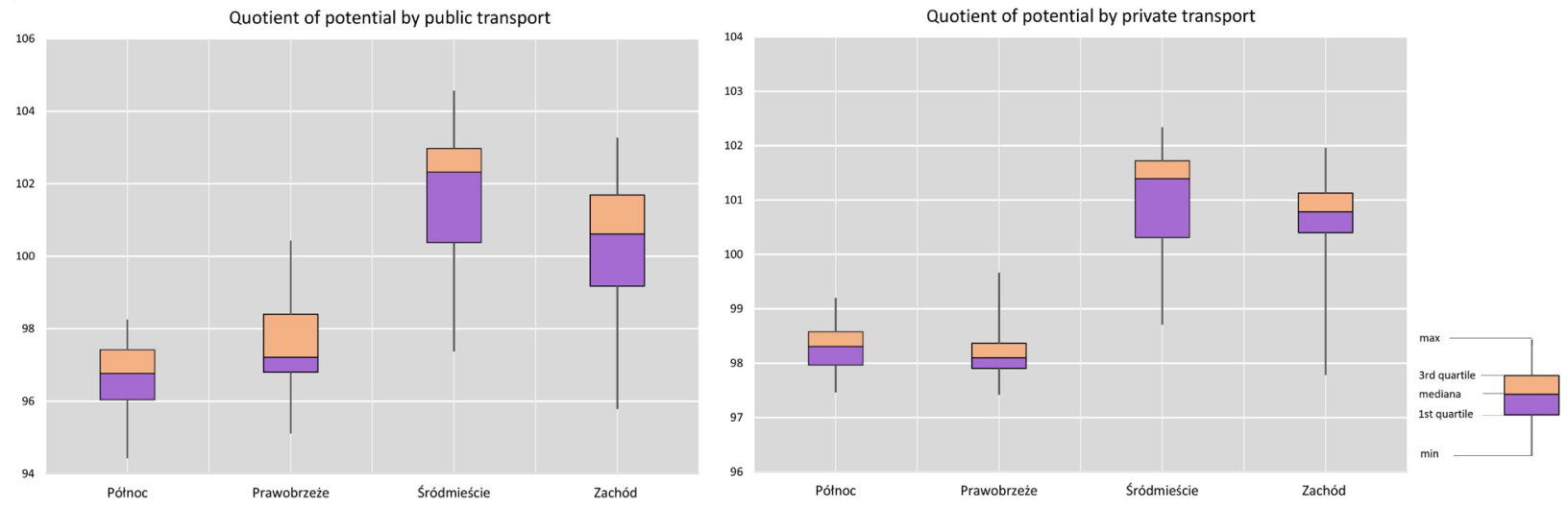

Figure 6. The results of the quotient of the potential of the working-age population by public and private transport, broken down into districts

Source: own elaboration

\section{Discussion}

A simple population potential accessibility indicator was used in this study in order to develop the potential quotient. It is a frequently used research method for measuring potential accessibility but there are also other methods. Numerous studies were based on the variability of accessibility (Merchant \& Nemhauser 1978) and the effectiveness of commuting (Niedzielski et al. 2020). Workplaces are often located outside the areas most densely populated with people of working age. Analyses concerning everyday commuting patterns using accessibility measures and potential quotient may indicate routes along which large numbers of people move during morning and afternoon peak hours. In the study there is only one parameter that differentiates travel time. However, the average travel time indicated in Comprehensive Traffic Research in Szczecin 2016 provides interesting results. Considering only those travel destinations selected in the study is an obvious limitation, yet the author states that using the workingage population and workplaces potential accessibility indicator significantly reduces the research gap.

\section{Conclusions}

The analysis of the working-age population potential and the workplaces potential indicators presented herein shows that their values largely depend on the location of travel sources and destinations (travel time needed to cover the distance between them). The border effect between the potential gets quickly blurred in places where a large disparity between the potentials is observed. The 6 value also affects the border effect. The larger the 6 value, the flatter the border effect. When calculating the border value, the distance to the means of transport is also of great importance. In the case of public transport, places located nearer the stops are more accessible and the effect is flatter. This is especially visible when analysing the data for certain districts of Szczecin (Figures 6 and 7). Prawobrzeże and Północ are distant from the areas where there is a concentration of workplaces. Thus, the values for those districts are the most extreme. In Śródmieście, and in the area bordering the Zachód district, there are numerous workplaces and a surplus of jobs. The maps depicting the workplaces potential quotient by private transport are not as flat. The potential quotient is largely affected by a particular city population size (Fig. 6). This was also confirmed in the study by Niedzielski \& Boschmann (2014). Citizens of smaller cities and towns usually cover short distances; consequently, the demand for transport services is lower. Walking is a common way of moving around smaller cities and towns (Toole et al. 2015). However, this is impossible in the case of Szczecin, which covers a considerable area and it is internally divided by a river. Commuting to work is one of the most important and frequent daily activities for people. It is also a major factor contributing to traffic congestion in cities, and Szczecin is no exeption. This was confirmed by the analysis of the potential accessibility in 2018, presented herein as well as by the results shown in Comprehensive Traffic Research in Szczecin 2016. Commuting to work is an activity that takes place mainly in the morning and afternoon. Nonetheless, the afternoon peak is usually longer and generates larger volumes of traffic (Loo \& Chow 2011, Shirgaokar 2014). Labour market accessibility is also seen in terms of housing stock and prices near large concentrations of work (Jiang et al. 2021). In this context, the distribution of jobs is important to avoid travel time during the day. It has become a popular practice for employers to change employee working hours in order to make the commuting schedules different from the tranditional morning and afternoon peak periods (Yongling \& Guonan 2009). Analyses of potential accessibility by public and private transport may be the first step in evaluating the locations of workplaces in relation to the spatial distribution of the working-age population in a given area. Applying such an approach allows the routes on which the largest flows of people are observed to be identified. Moreover, the potential accessibility indicator makes it possible to determine the modal division of transport and select the most efficient means of transport for a particular system and area. The potential accessibility quotient may also be useful when indicating areas where large infrastructural projects should be implemented. It is also an effective tool used to determine which district lacks workplaces, forcing their residents to cover larger distances when commuting to work. The analysis presented in this study confirms and explains the increased road traffic observed on routes connecting Prawobrzeże and Północ with Śródmieście and Zachód, which is also visible on maps of the afternoon peak published in Comprehensive Traffic Research in Szczecin 2016. Until now, the potential quotient method (Rosik et al. 2020) has rarely been used, even less so at a local scale. It is a valuable method that can illustrate the locations of increased traffic between settlements in a city.

\section{Funding}

This article is based on research funded by the National Science Centre under the number UMO-2017/25/N/HS4/01237 and UMO-2020/36/T/HS4/00131.

\section{ORCID}

Sławomir Goliszek (1D) https://orcid.org/0000-0003-0908-1487 


\section{References}

Allen, J 2019, 'Mapping differences in access to public libraries by travel mode and time of day', Library \& Information Science Research, vol. 41, no. 1, pp. 11-18.

Allen, J \& Farber, S 2019, 'Sizing up transport poverty: A national scale accounting of low-income households suffering from inaccessibility in Canada, and what to do about it', Transport Policy, vol. 74, pp. 214-223.

Assemi, B Baker, D \& Paz, A 2020, 'Searching for on-street parking: An empirical investigation of the factors influencing cruise time', Transport Policy, vol. 97, pp. 186-196.

Beria, P, Debernardi, A \& Ferrara, E 2017, 'Measuring the longdistance accessibility of Italian cities', Journal of Transport Geography, vol. 62, pp. 66-79.

Bok, J \& Kwon, Y 2016, 'Comparable Measures of Accessibility to Public Transport Using the General Transit Feed Specification', Sustainability, vol. 8 no. 3, 224.

Boussauw, K, Derudder, B \& Witlox, F 2011, 'Measuring spatial separation process through the minimum commute: the case of Flanders', European Journal of Transport and Infrastructure Research, vol. 11 no. 1, pp. 42-60.

Central Statistical Office, REGON database of companies in Szczecin. Available from: https://szczecin.stat.gov.pl/ cogdzie-jak-zalatwic/regon/ [10 March 2020].

City Hall of Szczecin, population in the age divided into districts 2009-2018. Available from: http://www.szczecin.pl/ chapter_59000.asp [11 May 2020].

Coffey, W (1978, 'Income Relationships in Boston and Toronto: A Tale for Two Countries?', Canadian Geographer, vol. 2, no. 22, pp. 112-129.

Comprehensive Traffic Research in Szczecin 2016. Available from: http://bip.um.szczecin.pl/chapter_11124.asp?soid= 2C19A077C8BE419985E3622664C0AA8D [10 February 2020].

Delling, D, Pajor, T \& Werneck, RF 2014, 'Round-based public transit routing', Transportation Science, vol. 49, no. 3, pp. 591-604.

El-Geneidy, A \& Levinson, D 2007, 'Mapping Accessibility Over Time', Journal of Maps, vol. 3, no. 1, pp. 76-87.

El-Geneidy, A, Buliung, R \& Diab, E 2015, 'Non-stop equity: Assessing daily intersections between transit accessibility and social disparity across the Greater Toronto and Hamilton Area (GTHA)', Environment and Planning B: Urban Analytics and City Science.

El-Geneidy, A, Levinson, D \& Diab, E 2016, 'The cost of equity: Assessing transit accessibility and social disparity using total travel cost', In 95th Annual Meeting of the Transportation Research Board, pp. 1-34. Washington D.C., USA.

Farber, S, Benjamin, R \& Liwei, F 2016, 'Space-time mismatch between transit service and observed travel patterns in the Wasatch Front, Utah: A social equity perspective', Travel Behaviour and Society, vol. 4, pp. 40-48.

Farber, S, Morang, MZ \& Widener, MJ 2014, 'Temporal variability in transit-based accessibility to supermarkets', Applied Geography, vol. 53, pp. 149-159.

Fielbaum, A, \& Jara-Diaz, S. 2021, 'Assessment of the sociospatial effects of urban transport investment using Google Maps APl', Journal of Transport Geography, 91, 102993.

Fransen, K, Neutens, T, Farber, S, De Maeyer, P, Deruyter, G \& Witlox, F 2015, 'Identifying public transport gaps using time-dependent accessibility levels', Journal of Transport Geography, vol. 48, pp. 176-187.

Gadziński, J \& Bul, R 2017, 'Planowanie przebiegu linii transportu zbiorowego $w$ oparciu o kryterium dostępności [Planning new public transport line based on accessibility criteria]', Przegląd Komunikacyjny, vol. 4, pp. 2-7.

Gadziński, J \& Beim, M 2010, 'Dostępność czasowa celów podróży przy dojazdach lokalnym transportem publicznym $w$ Poznaniu [Time accessibility of travel targets for accessing by means of local public transport in Poznan]', Transport Miejski i Regionalny, vol. 3, pp. 9-13.

Geurs, KT \& van Wee, B 2004, 'Accessibility evaluation of land use and transport strategies: Review and research directions', Journal of Transport Geography, vol. 12, no. 2, pp. 127-140.

Goliszek, S \& Połom, M 2016, 'The use of general transit feed specification (GTFS) application to identify deviations in the operation of public transport at morning rush hour on the example of Szczecin', Europa XXI, vol. 31, pp. 51-60.

Goliszek, S 2017, 'Space-time variation of accessibility to jobs by public transport - a case study of Szczecin', Europa XXI, vol. 33, pp. 49-66.

Goliszek, S 2021, 'GIS tools and programming languages for creating models of public and private transport potential accessibility in Szczecin, Poland', Journal of Geographical Systems, vol. 23, no. 1, pp. 115-137.

Goliszek, S, Połom, M \& Duma, P 2020, 'Potential and cumulative accessibility of workplaces by public transport in Szczecin', Bulletin of Geography. Socio-economic Series, vol. 50, pp. 133-146.

GTFS open data Szczecin. Available from: https://www.zditm. szczecin.pl/rozklady/GTFS/latest/. [22 July 2019].

Hadas, Y 2013, 'Assessing public transport systems connectivity based on Google Transit data', Journal of Transport Geography, vol. 33, pp. 105-116.

Hägerstrand, T 1970, 'What about people in regional science?', Papers of the Regional Science Association, vol. 24, no. 1, pp. 6-21.

Hansen, WG 1959, 'How accessibility shapes land-use', Journal of American Institute of Planners, vol. 25, pp. 73-76.

Harris, CD 1954, 'The market as a factor in the localization of industry in the United States', Annals of the Association of American Geographers, vol. 44, pp. 315-348.

Hongbo, Y \& Shih-Lung, S 2007, 'Revisiting Hägerstrand's timegeographic framework for individual activities in the age of instant access', Societies and Cities in the Age of Instant Access, pp. 103-118.

Jiang, L, Hagen-Zanker, A, Kumar, P, \& Pritchard, J 2021, 'Equity in job accessibility and environmental quality in a segmented housing market: The case of Greater London' Journal of Transport Geography, 90, 102-908.

Karner, A 2018, 'Assessing public transit service equity using route-level accessibility measures and public data', Journal of Transport Geography, vol. 67, pp. 24-32.

Kent, JL 2014, 'Driving to save time or saving time to drive? The enduring appeal of the private car', Transportation Research Part A: Policy and Practice, vol. 65, pp. 103-115.

Lagrell, E, Thulin, E \& Vilhelmson, B 2018, 'Accessibility strategies beyond the private car: A study of voluntarily carless families with young children in Gothenburg', Journal of Transport Geography, vol. 72, pp. 218-227.

Lei, T \& Von u Thakuriah, P 2012, 'Ridership effects of real-time bus information system: A case study in the City of Chicago', Transportation Research Part C: Emerging Technologies, vol. 22, pp. 146-161.

Levinson, D M \& King, D 2020, 'Transport Access Manual', 229, Sydney. 
Loo, B \& Chow, A 2011, 'Jobs-housing balance in an era of population decentralization: an analytical framework and a case study', Journal of Transport Geography, vol. 19 no. 4, pp. 552-562.

Martínez-Jiménez, E \& Salinas-Pérez, JA 2019, 'Accessibility to culture and education. Educative city of Córdoba (Spain)', Journal of Maps, vol. 15, no. 1, pp. 39-45.

Merchant, DK \& Nemhauser GL 1978, 'A model and an algorithm for the dynamic traffic assignment problems', Transportation Science, vol. 12, no. 3, pp. 183-199.

Miller, HJ 1991, 'Modelling accessibility using space-time prism concepts within geographical information systems', International Journal of Geographical Systems, vol. 5, no. 3, pp. 287-301.

Moya-Gómez, B \& García-Palomares, JC 2017, 'The daily dynamic potential accessibility by car in London on Wednesdays', Journal of Maps, vol. 13, no. 1, pp. 31-39.

Neutens, T 2015, 'Accessibility, equity and health care: review and research directions for transport geographers', Journal of Transport Geography, vol. 43, pp. 14-27.

Niedzielski, MA 2006, 'A spatially disaggregated approach to commuting efficiency', Urban Studies, vol. 43, no. 13, pp. 2485-2502.

Niedzielski, MA \& Boschmann, EE 2014, 'Travel time and distance as relative accessibility in the journey to work', Annals of the Association of American Geographers vol. 104, pp. 1156-1182.

Niedzielski, MA \& Śleszyński, P 2008, 'Analyzing accessibility by transport mode in Warsaw, Poland', Geographia Polonica, vol. 81, no. 2, pp. 61-78.

Niedzielski, MA Hu, Y \& Stępniak, M 2020 , 'Temporal dynamics of the impact of land use on modal disparity in commuting efficiency', Computers, Environ and Urban Sys, vol. 83, 101523.

O'Kelly, ME \& Lee, W 2005, 'Disaggregate journey-to-work data: implications for excess commuting and jobs-housing balance', Environment and Planning A, vol. 37, no. 12, pp. 2233-2252.

O'Kelly, ME \& Niedzielski, MA 2008, 'Efficient spatial interaction: attainable reductions in metropolitan average trip length', Journal of Transport Geography vol. 16, no. 5, pp. 313-323.

O'Kelly, ME \& Niedzielski, MA 2009, 'Are long commute distances inefficient and disorderly?', Environment \& Planning A: Economy and Space, vol. 41, no. 11, pp. 2741-2759.

O'Kelly, ME, Niedzielski, MA \& Gleeson, J 2012, 'Spatial Interaction Models from Irish Commuting Data: Variations in Trip Length by Occupation and Gender', Journal of Geographical Systems, vol. 14, no. 4, pp. 357-387.

Owen, A \& Levinson D 2015, 'Modeling the commute mode share of transit using continuous accessibility to jobs', Transportation Research Part A: Policy and Practice, vol. 74, pp. 110-122.

Poelman, H \& Dijkstra, L 2015, 'Measuring access to public transport in European cities', Regional Working Paper.

Ritsema van Eck J, Burghouwt G, Dijst M 2005, 'Lifestyles, spatial configurations and quality of life in daily travel: an explorative simulation study', Journal of Transport Geography, vol. 13, pp. 123-134.

Rosik, P, Pomianowski, W, Komornicki, T, Goliszek, S, SzejgiecKolenda, B \& Duma, P 2020, 'Regional dispersion of potential accessibility quotient at the intra-European and intranational level. Core-periphery pattern, discontinuity belts and distance decay tornado effect', Journal of Transport Geography, vol. 82, 102-554.
Rosik, P, Puławska-Obiedowska, S \& Goliszek S 2021, 'Public transport accessibility to upper secondary schools measured by the potential quotient: The case of Kraków', Moravian Geographical Reports, vol. 29, no. 1, pp. 15-26.

Rosik, P, Stępniak, M \& Wiśniewski, R 2010, ' Dojazdy do pracy do Warszawy i Białegostoku - alternatywne podejścia metodologiczne [Commuting to Warsaw and Białystok Alternative Methodological Approaches]', Studia Regionalne i Lokalne, vol. 2, pp. 77-98.

Salonen, M \& Toivonen, T 2013, 'Modelling travel time in urban networks: Comparable measures for private car and public transport', Journal of Transport Geography, vol. 31, pp. 143-153.

Shearmur, R 2006, 'Travel from home: an economic geography of commuting distances in Montreal', Urban Geography, vol. 27, no. 4, pp. 330-359.

Shirgaokar, M 2014, 'Employment centers and travel behavior: exploring the work commute of Mumbai's rapidly motorizing middle class', Journal of Transport Geography, vol. 41, pp. 249-258

Stępniak, M \& Goliszek, S 2017, 'Spatio-temporal variation of accessibility by public transport - the equity perspective', [w:] Red. Igor Ivan, Alex Singleton, Jiří Horák, Tomáš Inspektor, The rise of big spatial data, Lecture Notes in Geoinformation and Cartography, Springer International Publishing, Cham,. 241-261

Stępniak, M, Pritchard, J, Geurs, KT \& Goliszek, S 2019, 'The impact of temporal resolution on public transport accessibility measurement: Review and case study in Poland', Journal of Transport Geography, vol. 75, no. 2, pp. 8-24.

Sweet, M Harrison, C Kanaroglou, P 2015, 'Congestion Trends in the City of Toronto (2011-2014)', McMaster Institute for Transportation and Logistics, Hamilton, Ontario.

Ting, LL \& Church, RL 2010, 'Mapping transit-based access: integrating GIS, routes and schedules', International Journal of Geographical Information Science, vol. 24, no. 2, pp. 283-304.

Toole, JL, Colak, S, Sturt, B, Alexander, LP, Evsukoff, A \& Gonzalez, MC 2015, 'The path most travelled: Travel demand estimation using big data resources', Transportation Research Part C: Emerging Technologies, vol. 58, pp.162177.

Vickerman, R, Spiekermann, K \& Wegener, M 1999, 'Accessibility and Economic Development in Europe', Regional Studies vol. 33, no. 1, pp. 1-15.

Vickerman, RW 1974, 'Accessibility, attraction and potential: $A$ review of some concepts and their use in determining mobility', Environment and Planning A, vol. 6, pp. 675-691.

Wang, CH \& Chen, N 2015, 'A GIS-based spatial statistical approach to modelling job accessibility by transportation mode: case study of Columbus, Ohio', Journal of Transport Geography, vol. 45, pp. 1-11.

Wang, $\mathrm{F} \& \mathrm{Xu}, \mathrm{Y} 2011$, 'Estimating O-D matrix of travel time by Google Maps API: Implementation, advantages and implications', Annals of GIS, vol. 17, pp. 199-209.

Wang, L, Li, L, Wu, B \& Bai Y 2013, 'Private Car Switched to Public Transit by Commuters, in Shanghai, China', Procedia - Social and Behavioral Sciences, vol. 96, pp. 1293-1303.

Wessel, N \& Widener, M 2016, 'Discovering the space-time dimensions of schedule padding and delay from GTFS and real-time transit data', Journal of Geographical Systems, col. 19 , pp. 93-107.

Wessel, N, Allen, J \& Farber, S 2017, 'Constructing a Routable Retrospective Transit Timetable from a Real-time Vehicle 
Location Feed and GTFS', Journal of Transport Geography, vol. 62, pp. 92-97.

Widener, MJ, Farber, S, Neutens, T \& Horner, M 2015, 'Spatiotemporal accessibility to supermarkets using public transit: an interaction potential approach in Cincinnati. Ohio', Journal of Transport Geography, vol. 42, pp. 72-83.

Widener, MJ, Minaker, LM, Farber, S, Allen, J, Vitali, B, Coleman, PC \& Cook, B 2017, 'How do changes in the daily food and transportation environments affect grocery store accessibility?', Applied Geography, vol. 83, pp. 46-62.

Yongling, Y \& Guonan, Z 2009, 'Empirical analysis of spatial mismatch of living-working: based on a field survey in downtown Beijing', International Journal of Urban Sciences, vol. 13, no. 1, pp. 1-17. 